University of Nebraska - Lincoln

DigitalCommons@University of Nebraska - Lincoln

DRY MATTER PRODUCTION AND LEAF ELEMENTAL CONCENTRATIONS OF RAMBUTAN GROWN ON AN ACID ULTISOL

Ricardo Goenaga

USDA-ARS, Ricardo.Goenaga@ars.usda.gov

Follow this and additional works at: https://digitalcommons.unl.edu/usdaarsfacpub

Part of the Agricultural Science Commons

Goenaga, Ricardo, "DRY MATTER PRODUCTION AND LEAF ELEMENTAL CONCENTRATIONS OF

RAMBUTAN GROWN ON AN ACID ULTISOL" (2011). Publications from USDA-ARS / UNL Faculty. 533.

https://digitalcommons.unl.edu/usdaarsfacpub/533

This Article is brought to you for free and open access by the U.S. Department of Agriculture: Agricultural Research Service, Lincoln, Nebraska at DigitalCommons@University of Nebraska - Lincoln. It has been accepted for inclusion in Publications from USDA-ARS / UNL Faculty by an authorized administrator of DigitalCommons@University of Nebraska - Lincoln. 


\title{
DRY MATTER PRODUCTION AND LEAF ELEMENTAL CONCENTRATIONS OF RAMBUTAN GROWN ON AN ACID ULTISOL
}

\section{Ricardo Goenaga}

USDA-ARS, Tropical Agriculture Research Station, Mayaguez, Puerto Rico

\begin{abstract}
$\square \quad$ Little is known about the adaptability of rambutan (Nephelium lappaceum) to highly acidic soils rich in aluminum (Al). A 2-yr field study was conducted to determine the effects of various levels of soil Al on dry matter production, plant growth, and nutrient concentration in the leaves of four cultivars of rambutan. Cultivars and the cultivar $x$ year interaction were not statistically significant for most variables measured in the study. Total, leaf, petiole, stem and root dry weights significantly increased at soil Al concentrations ranging from $0.67 \mathrm{cmol} \mathrm{kg}^{-1}$ to $11.0 \mathrm{cmol} \mathrm{kg}^{-1}$. At this range of soil $\mathrm{Al}$, the concentrations of $\mathrm{Al}$ and manganese $(\mathrm{Mn})$ in leaf tissue declined sharply. The results of this study demonstrate that rambutan is highly tolerant to acid soils and that tolerance may involve an Al- and Mn- exclusion mechanism.
\end{abstract}

Keywords: Nephelium lappaceum, soil acidity, aluminum

\section{INTRODUCTION}

Rambutan (Nephelium lappaceum L.) is a member of the Sapindaceae family and along with other important fruit crops such as lychee and longan is native to South East Asia (Tindall, 1994). The edible portion of the rambutan fruit is a fleshy, translucent white sarcotesta, which arises from an integument surrounding a single oblong seed. Currently, Thailand is the leading producer of rambutan worldwide (Zee et al., 1998); however, Indonesia, Malaysia, Australia and some countries in the western hemisphere also produce this fruit commercially. As with many other tropical fruit crops there is a scarcity of information on best management practices and optimum growing conditions for rambutan. For example, little is known about the adaptability of rambutan to highly acidic soils. The most productive soils

This article not subject to US copyright law.

Received 23 April 2009; accepted 23 April 2010.

Address correspondence to Ricardo Goenaga, USDA-ARS, Tropical Agriculture Research Station, 2200 P.A. Campos Ave., Suite 201, Mayaguez, Puerto Rico 00680-5470. E-mail: Ricardo.Goenaga@ ars.usda.gov 
of the world are already under cultivation, and those available for agricultural expansion are often strongly acidic, possessing toxic levels of soil aluminum. (Kamprath, 1984; Samac and Tesfaye, 2003).

The mechanism by which soil acidity reduces the yield of many crops has been studied extensively (Foy, 1984; Kochian et al., 2002). A high concentration of soil aluminum $(\mathrm{Al})$ restricts root growth and hence exploitation of the soil/subsoil by roots for moisture and nutrients. Soil aluminum as high as $15 \mathrm{cmol} \mathrm{kg}^{-1}$ can be found in tropical acid soils; in the tropical Americas, about $50 \%$ of the soils with potential for agricultural use have been diagnosed with aluminum toxicity problems (National Research Council, 1993; Villagarcia et al., 2001; Hoekenga et al., 2006).

Few studies, if any, have been conducted to screen rambutan germplasm for acid soil tolerance under field conditions. Ongoing research conducted by the author on the evaluation of promising rambutan germplasm for horticultural traits suggests that this crop adapts well to acid soils. The objective of this investigation was to determine the critical soil $\mathrm{Al}$ concentrations that affect growth of rambutan germplasm under field conditions and to identify potential sources of tolerance to this stress.

\section{MATERIALS AND METHODS}

Field experiments were established 29 October 2002 and 26 November 2003 at the Corozal Research Station of the University of Puerto Rico. The study was conducted on a deep, well-drained Ultisol (Aquic Tropudult) in 28- $3.65 \times 3.65 \mathrm{~m}$ blocks arranged in a randomized complete block design. Blocks differed in soil acidity due to differential applications of calcitic limestone over a period of years prior to the experiment. Soil from each block was sampled before planting by taking 10 borings at a depth of $0-15 \mathrm{~cm}$ from each plot. The samples were air-dried and passed through a 20-mesh screen. Soil $\mathrm{pH}$ in water and $0.01 \mathrm{M}$ calcium chloride $\left(\mathrm{CaCl}_{2}\right)(1: 2$ soil:water $)$ were measured with a glass electrode. Potassium chloride $(\mathrm{KCl})$ extractable $\mathrm{Al}$ was determined using an atomic absorption spectrophotometer, and exchangeable cations, extracted with neutral $1 \mathrm{M}$ ammonium acetate $\left(\mathrm{NH}_{4} \mathrm{OAc}\right)$, were similarly determined. Percent Al saturation of the soil was calculated on the assumption that exchangeable calcium $(\mathrm{Ca})+$ magnesium $(\mathrm{Mg})+$ potassium $(\mathrm{K})+\mathrm{Al}+$ hydrogen $(\mathrm{H})$ was the effective cation exchange capacity of the soil (Kamprath, 1984).

All plots were planted to open-pollinated seedlings of rambutan clones 'Binjai', 'Jit Lee,' 'R-134' and 'R-162'. Seedlings were approximately two months-old and had an average height and leaf number of $28.3 \mathrm{~cm}$ and 7.3 leaves, respectively when transplanted to the field. 'Binjai' is a cultivar from Indonesia, 'Jit Lee' from Singapore, and 'R-134' and 'R-162' are cultivars from a selection program initiated in Malaysia in the late 1970s (Tindall, 
1994). To our knowledge, these cultivars have never been field-tested under a wide range of soil $\mathrm{Al}$ concentrations which, in this study, ranged from 0.67 to $17 \mathrm{cmol} \mathrm{kg}^{-1}$. The $\mathrm{pH}_{\mathrm{H} 2 \mathrm{O}}$ and $\mathrm{pH}_{\mathrm{CaCl} 2}$ in these plots ranged from 3.54 to 4.90 and 2.72 to 4.21 , respectively. A 3 m row $\left(10\right.$ plants row $\left.{ }^{-1}\right)$ of each cultivar was planted in each block. Rows were $61 \mathrm{~cm}$ apart with plants 30.5 $\mathrm{cm}$ apart within the row. Plants in each row were side-dressed with a 10-2.2 12.5-1.8 [nitrogen (N)- phosphorus (P)-K-Mg] commercial mixture applied at a rate of $670 \mathrm{~kg} \mathrm{ha}^{-1}$ two weeks after planting.

Trees were harvested for biomass accumulation on September 30, 2003 in experiment 1, and October 18, 2004 in experiment 2, about 11 months after field transplanting. At each harvest, soil was loosened with a garden fork and eight plants from each cultivar in each row pulled from the soil, washed and separated into leaves, petioles, stem and roots. Plant parts from each variety were dried at $70^{\circ} \mathrm{C}$ to constant weight for dry matter determination. The dry samples were ground to pass a 1.0-mesh screen and analyzed for $\mathrm{N}$, $\mathrm{P}, \mathrm{K}, \mathrm{Ca}, \mathrm{Mg}$, iron $(\mathrm{Fe}), \mathrm{Al}$, and manganese $(\mathrm{Mn})$. Nitrogen was determined by the micro-Kjeldahl procedure (IBSNAT, 1987), P by the molybdovanadophosphoric acid method (IBSNAT, 1987), and K, Ca, Mg, Fe, Al, and Mn by atomic absorption spectrometry (Perkin-Elmer, 1994). Analyses of variance and regression analyses were determined using the GLM procedure of the SAS program package (SAS Institute, Cary, NC, USA). Only coefficients at $P \leq 0.05$ were retained in the models.

\section{RESULTS AND DISCUSSION}

Differences among soil Al treatments were highly significant $(P<0.01)$ for total, leaf, stem, petiole, and root dry weight at the end of the experimental period (analysis of variance not shown). Cultivars and the cultivar $\mathrm{x}$ year interaction were not significant. Therefore, results were averaged over cultivars and years.

Increasing soil $\mathrm{Al}$ concentration from about $0.67 \mathrm{cmol} \mathrm{kg}^{-1}$ to 11.0 $\mathrm{cmol} \mathrm{kg}^{-1}$ resulted in an increase in total dry weight by more than $145 \%$ (Figure 1A) with leaf, petiole, stem and root dry weights increasing $160 \%$, $179 \%, 149 \%$ and 122\%, respectively (Figures 1B-E). Soil Al concentrations higher than $11.0 \mathrm{cmol} \mathrm{kg}^{-1}$ resulted in a significant reduction of dry weight in all plant parts (Figures 1B-E). At soil Al concentrations of 0.67 and 11.0

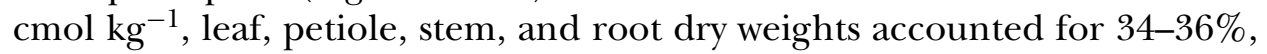
$7-8 \%, 30-31 \%$, and $28-25 \%$, respectively, of the total dry weight. As with dry matter accumulation, stem diameter and plant height significantly increased until soil $\mathrm{Al}$ reached a concentration of about $11 \mathrm{cmol} \mathrm{kg}^{-1}$ and then declined (Figures 2A and 2B). The increase in plant dry weight, plant height and stem diameter with increasing levels of soil $\mathrm{Al}$ up to $11 \mathrm{cmol} \mathrm{kg}^{-1}$ of soil $\mathrm{Al}$ indicates that rambutan is highly tolerant to high soil $\mathrm{Al}$. These results 


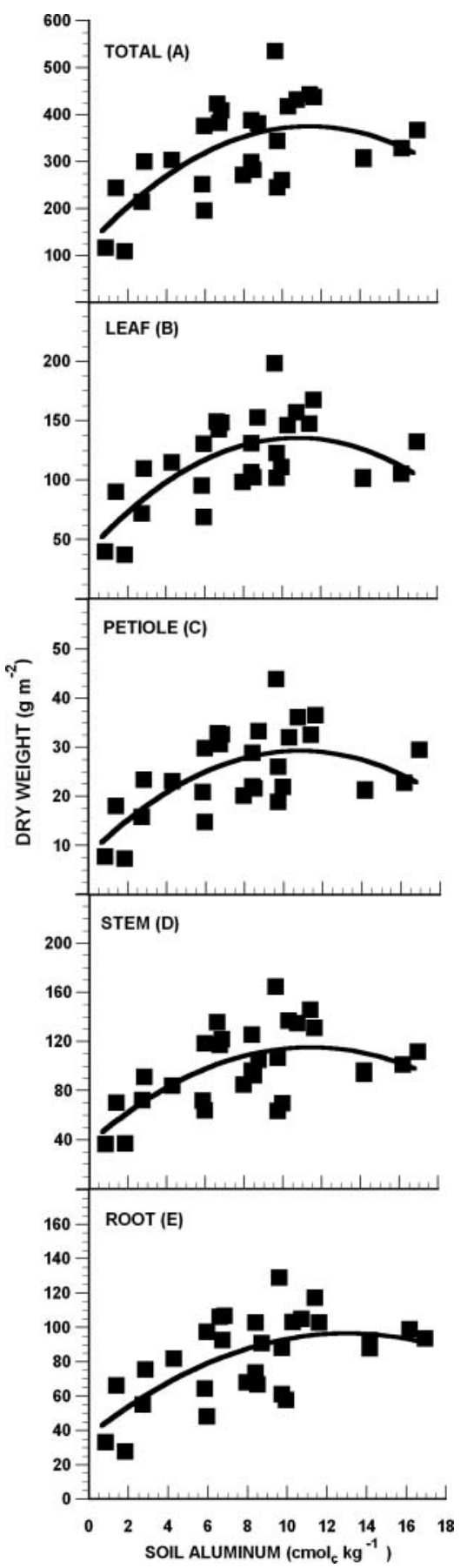

FIGURE 1 Dry weight of plant organs of rambutan as influenced by soil aluminum. 


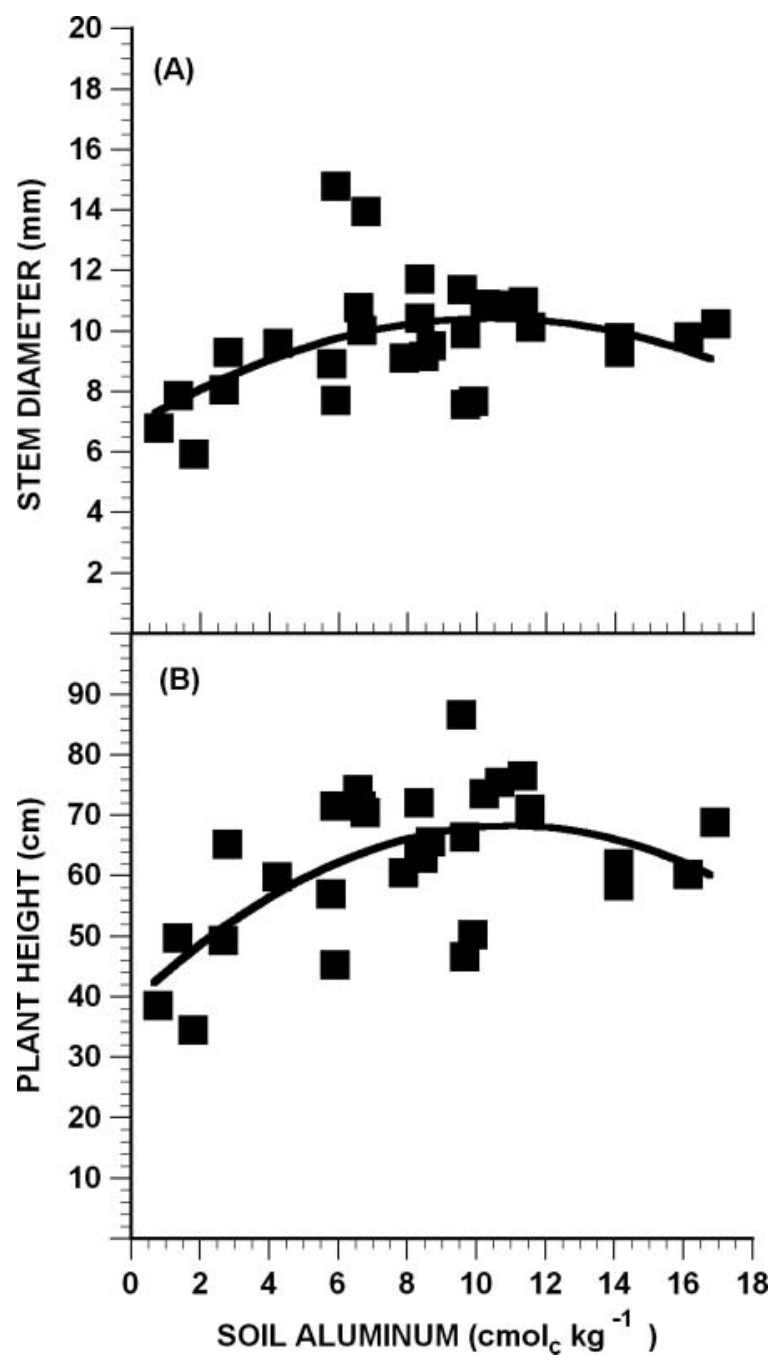

FIGURE 2 Stem diameter (A) and plant height (B) of rambutan as influenced by soil aluminum.

differ greatly from similar studies conducted with other crops at the same site. Goenaga and Smith (2002) found that increasing soil Al concentration from $0.68 \mathrm{cmol} \mathrm{kg}^{-1}$ to just $2.5 \mathrm{cmol} \mathrm{kg}^{-1}$ reduced total dry weight of five common bean (Phaseolus vulgaris L.) genotypes between $25 \%$ and $31 \%$. Working with pigeon peas (Cajanus cajan), a crop reputed to be drought tolerant, Abruña et al. (1984) found that increasing the soil $\mathrm{Al}$ saturation from $0 \%$ to $51 \%$ resulted in a yield reduction of $46 \%$. In contrast, growth of rambutan in our study was unaffected until the soil reached an $\mathrm{Al}$ concentration of $11.0 \mathrm{cmol} \mathrm{kg}^{-1}$ which represented about $66 \%$ soil Al saturation (Figures 1 and 3). Growth of various crops such as corn, wheat, soybean, sweet potato, and Brachiaria on acid soils with Al saturation greater than $60 \%$ was less 


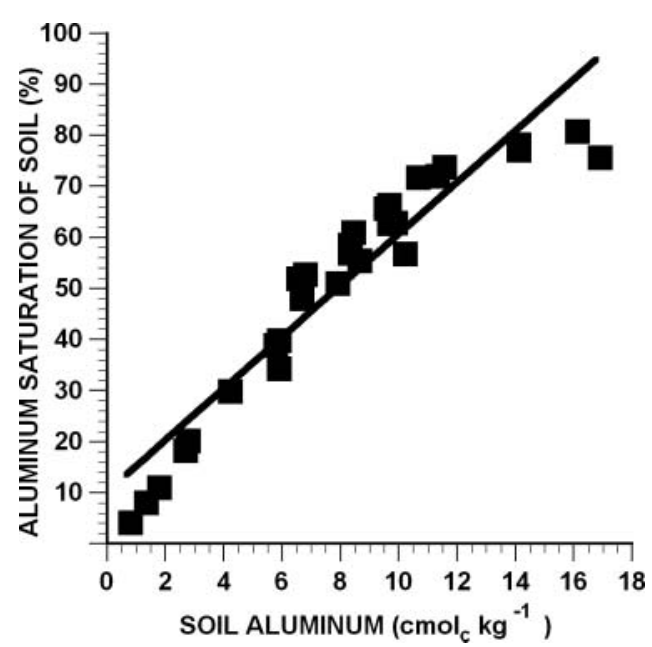

FIGURE 3 Relationship between soil aluminum and aluminum saturation in an Ultisol in Corozal, Puerto Rico.

than half of the growth observed when the soil was limed (Kamprath, 1984) providing further evidence of $\mathrm{Al}$ tolerance in rambutan.

Figure 4 shows the concentration of various nutrients in leaves collected at the end of the experimental period. The concentration of leaf $\mathrm{N}$ was not significantly affected by levels of soil Al. As expected, increments in soil $\mathrm{Al}$ resulted in significant reductions in the concentration of leaf $\mathrm{P}, \mathrm{Ca}$, and $\mathrm{Mg}$ (Figures 4B, 4D, and 4E). Symptoms of P, Ca, and Mg deficiencies often occur on plants that are exposed to high levels of soil Al (Fageria et al., 2006). However this was not the case in the present study whereby dry matter production, stem diameter and plant height were unaffected until very high levels of soil $\mathrm{Al}\left(<11 \mathrm{cmol} \mathrm{kg}^{-1}\right)$ were surpassed (Figures 1A-1E; Figures 2A-2B). At a soil Al level of $11.0 \mathrm{cmol} \mathrm{kg}^{-1}$ the concentration of $\mathrm{P}, \mathrm{Ca}$, and $\mathrm{Mg}$ on leaf tissue was $0.15 \%, 0.72 \%$ and $0.13 \%$, respectively. These concentrations are similar to those found in productive rambutan orchards established on acid soils and sampled by the author (unpublished data). Therefore, it appears that these leaf nutrient concentrations are not sufficiently low as to cause deficiency symptoms in rambutan.

Leaf K concentration increased and then plateaued with increments in soil Al (Figure 4C). In sorghum (Duncan et al., 1980), plantain (RodriguezGarcía et al., 1985), and common bean (Goenaga and Smith, 2002), Al toxicity has been associated with increased concentration of $\mathrm{K}$ in the plant shoot.

High concentrations of tissue $\mathrm{Al}, \mathrm{Fe}$, and $\mathrm{Mn}$ can limit plant growth and reduce crop yields (Fageria et al., 2006; Kochian et al., 2002; Nagasaka et al., 2002; Nguyen et al., 2005; Langer et al., 2009). It is noteworthy that in the present study $\mathrm{Al}$ and Fe concentrations in leaf tissue declined with 

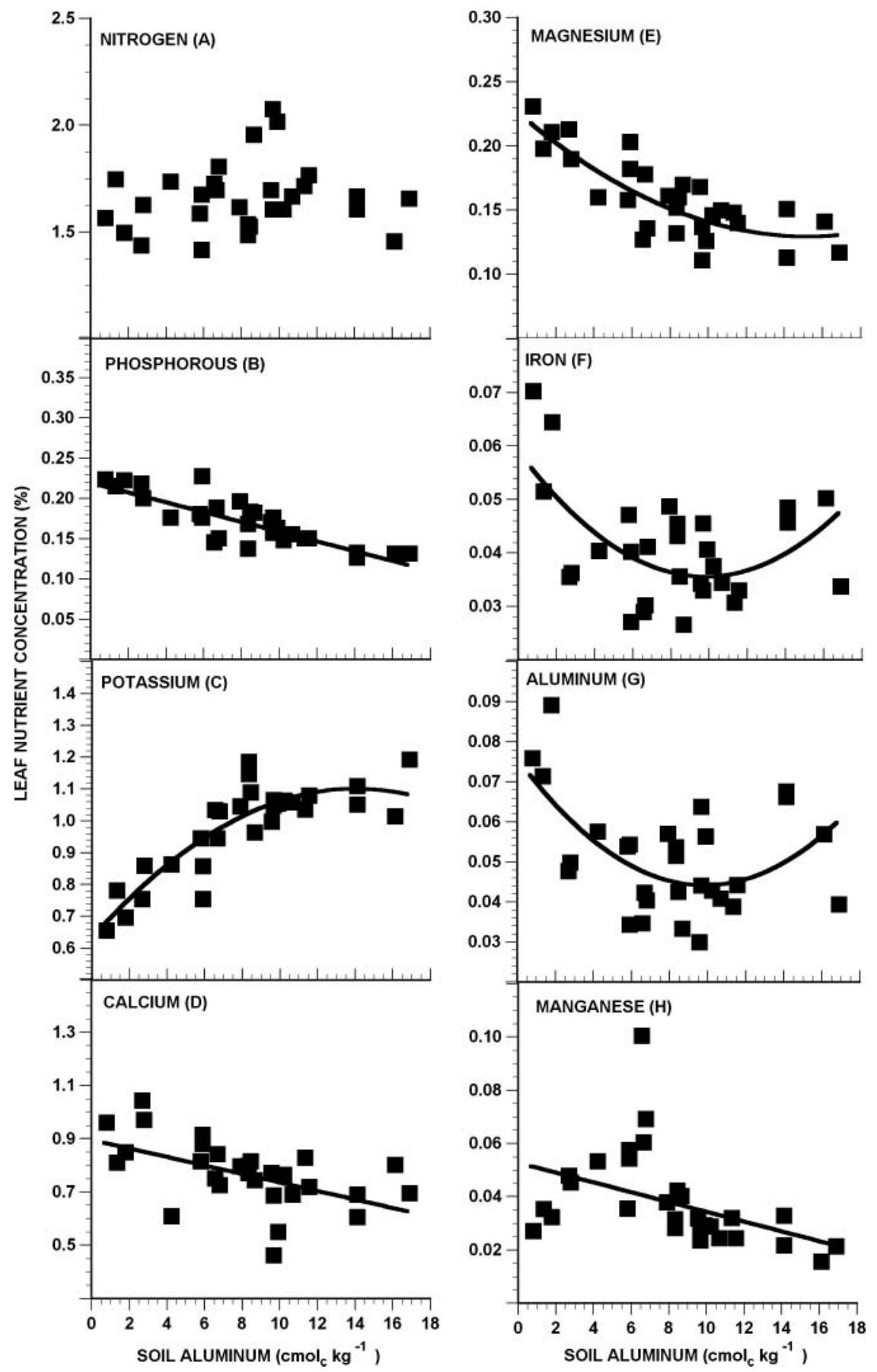

FIGURE 4 Leaf nutrient concentration of rambutan as influenced by soil aluminum. Absence of curve fitting denotes lack of a significant response. 
increments in soil $\mathrm{Al}$ (Figures 4F, 4G) and then increased at exactly the same soil $\mathrm{Al}$ concentration $\left(11 \mathrm{cmol} \mathrm{kg}^{-1}\right)$ in which rambutan dry weight commenced to decline (Figures 1A-1E). These results are opposite to those found by others in which the concentrations of these nutrients increased significantly with increases in soil Al (Duncan et al., 1980; Goenaga and Smith, 2002) and suggests a very strong Al-exclusion mechanism rendering tolerance to rambutan. Various investigators have suggested the role of organic acid anion exudation from the root apex as a means for Al exclusion (Kochian et al., 2002; Watanabe and Osaki, 2002; Fageria et al., 2006). Leaf Mn declined linearly with increases in soil Al (Figure 1H) suggesting also the presence of a Mn-exclusion mechanism. Rosas et al. (2007) found that roots of white clover exuded organic acids, particularly citrate, oxalate and malate, when plants were grown at high Mn concentration. These results showed the formation of organic acid-Mn complexes in response to increases in Mn concentration in the nutrient solution but the authors could not prove conclusively whether exudation of organic acids is a plant strategy for overcoming $\mathrm{Mn}$ toxicity as it is for $\mathrm{Al}$ toxicity. In this study, rambutan plants were not only shown to be very tolerant to high soil Al but also to the whole soil acidity complex encountered under field conditions. Future research conducted by the author will hopefully help to discern its mechanism for acid soil tolerance.

\section{CONCLUSIONS}

The results of this study demonstrate that growth of rambutan is not affected when grown at soil $\mathrm{Al}$ concentrations as high as $11 \mathrm{cmol} \mathrm{kg}^{-1}$. The concentration of leaf $\mathrm{Al}$ declined sharply between 0.67 to $11 \mathrm{cmol} \mathrm{kg}^{-1}$ of soil Al, suggesting the activation of an Al-exclusion mechanism. The author is not aware of other fruit crop species which thrive under the high soil $\mathrm{Al}$ levels encountered by rambutan trees in this study. Therefore, future studies should be directed toward the identification of this mechanism.

\section{ACKNOWLEDGMENTS}

Appreciation is expressed to Nicolás Díaz, Angel Marrero, and Ulises Chardón for assistance in data collection, tissue processing and chemical analyses of samples and to Dr. Francis Zee, USDA-ARS, Hilo, Hawaii for assistance in obtaining rambutan germplasm.

\section{REFERENCES}

Abruña, F., E. Rivera, and J. A. Rodríguez-García. 1984. Crop responses to soil acidity factors in Ultisols and Oxisols in Puerto Rico. X. Pigeon Peas. Journal of Agriculture of the University of Puerto Rico 68: 433-443. 
Duncan, R. R., J. W. Dobson, and C. D. Fisher. 1980. Leaf elemental concentrations and grain yield of sorghum grown on an acid soil. Communications in Soil Science and Plant Analysis 11: 699-707.

Fageria, N. K., V. C. Baligar, and R. B. Clark. 2006. Physiology of Crop Production. New York: The Hayworth Press.

Foy, C. D., 1984. Physiological effects of hydrogen, aluminum, and manganese toxicities in acid soil. In: Soil Acidity and Liming, ed. F. Adams, pp. 57-97. Madison, WI: American Society of Agronomy.

Goenaga, R., and J. R. Smith. 2002. Dry matter production and leaf elemental concentrations of common bean grown on an acid ultisol. Journal of Plant Nutrition 25: 103-112.

Hoekenga, O., L. G. Maron, M. A. Pineros, G. M. Cancado, J. Shaff, Y. Kobayashi, P. R. Ryan, B. Dong, E. Delhaize, T. Sasaki, H. Matsumoto, H. Koyama, and L. V. Kochian. 2006. Atalmt1 (atlg08430) which encodes a malate transporter, is identified as one of several genes critical for aluminum tolerance in Arabidopsis. Proceedings of the National Academy Science 103: 9738-9743.

IBSNAT. 1987. Field and laboratory methods of IBSNAT. Technical Report. Department of Honolulu: Agronomy and Soil Sciences, College of Tropical Agriculture and Human Resources, University of Hawaii.

Kamprath, E. J. 1984. Crop responses to lime on soils in the tropics. In: Soil Acidity and Liming, ed. F. Adams, pp. 349-368. Madison, WI: American Society of Agronomy.

Kochian, L. V., N. S. Pence, D. L. D. Letham, M. A. Pineros, J. V. Magalhaes, O. W. Hoekenga, and D. F. Garvin. 2002. Mechanisms of metal resistance in plants: Aluminum and heavy metals. Plant and Soil 247: 109-119.

Langer, H., M. Cea, G. Curaqueo, and F. Borie. 2009. Influence of aluminum on the growth and organic acid exudation in alfalfa cultivars grown in nutrient solution. Journal of Plant Nutrition 32: 618-628.

Nagasaka, S., N. K. Nishizawa, T. Negishi, K. Sataka, S. Mori, and E. Yoshimura. 2002. Novel iron-storage particles may play a role in aluminum tolerance of Cyanidium caldarium. Planta 215: 399-404.

National Research Council. 1993. Sustainable Agriculture and the Environment in the Humid Tropics. Committee on sustainable agriculture and the environment in the humid tropics. Board on Agriculture and Board on Science and Technology for International Development. Washington, DC: National Academy Press.

Nguyen, N. T., N. D. Hiep, and K. Fujita. 2005. Iron enhances aluminum-induced leaf necrosis and plant growth inhibition in Eucalyptus camaldulensis. Plant and Soil 277:139-152.

Perkin-Elmer, 1994. Analytical methods for atomic absorption spectrometry. Norwalk, CT: The PerkinElmer Corporation.

Rodríguez-García, J., E. Rivera, and F. Abruña. 1985. Crops response to soil acidity factors in Ultisols and Oxisols in Puerto Rico. XIV. Plantains and Bananas. Journal of Agriculture of the University of Puerto Rico 59: 377-382.

Rosas, A., Z. Rengel, and M. D. L. Mora. 2007. Manganese supply and pH influence growth, carboxylate exudation and peroxidase activity of ryegrass and white clover. Journal of Plant Nutrition 30: 253-270.

Samac, D. A., and M. Tesfaye. 2003. Plant improvement for tolerance to aluminum in acid soils-A review. Plant Cell, Tissue and Organ Culture 75: 189-207.

Tindall, H. D. 1994. Rambutan cultivation. FAO Plant Production and Protection Paper 121. Rome: Food and Agriculture Organization of the United Nations.

Villagarcia, M. R., T. E. Carter, T. W. Rufty, A. S. Niewoehner, M. W. Jennette, and C. Arellano. 2001. Genotypic rankings for aluminum tolerance of soybean roots grown in hydroponics and sand culture. Crop Science 41: 1499-1507.

Watanabe, T., and M. Osaki. 2002. Mechanisms of adaptation to high aluminum condition in native plant species growing in acid soils: A review. Communications in Soil Science and Plant Analysis 33: 1247-1260.

Zee, F. T. P., H. T. Chan, and C. R. Yen. 1998. Lychee, longan, rambutan and pulasan. In: Tropical and Subtropical Fruits, eds. P. E. Shaw, H. T. Chen, and S. Nagy, pp. 290-335. Auburndale, FL: AgScience, Inc. 